\title{
Implication of E-Tourism on Culture Value of Community Based Tourism in Indonesia
}

\author{
Bernadette Dian Nugraheni, S.Sos. ${ }^{\text {a }}$ and Ismi Dwi Astuti Nurhaeni, Prof. Dr., M.Si., \\ ${ }^{a}$ Communication Study Program, Universitas Sebelas Maret, Kentingan, Surakarta, Central

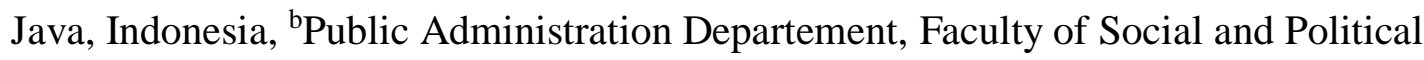 \\ Sciences, Universitas Sebelas Maret, Kentingan, Surakarta, Central Java, Indonesia \\ abernadettediannugraheni@student.uns.ac.id, bismidwiastuti@staff.uns.ac.id
}

\begin{abstract}
Based on initial data from the digital Yearbook in 2017, the internet users in Indonesia have reached $51 \%$, and $40 \%$ of social media users. An indication of this, the Central Government did a digital tourism policy (E-tourism) was considered appropriate for Indonesia's tourism development, so that it could grab the number of visits of tourists to 20 million by the year 2019. E-tourism is expected to give a significant impact on the development of Indonesia's tourism, as a marketing platform through the infinite gives comfort and efficiency of the place and the cost. This article focuses on the implications caused by E-tourism on the value to the community based tourism (CBT) institutional value. CBT is a form of community-based tourism development established by local people and recognized by the local authorities and the Central Government. Data collection is done by a review of the literature in the last 10 years. Literature review consists of two parts. In the first part, we will look at closely about e-tourism. In the second part, we will assess the value of innovation in CBT. The results can be expressed that values CBT experience some change as a form of adaptability during the era of digitization. Implications or changes that occur with the introduction of e-tourism in early stage of CBT CBT is interested in managing a business by the entrepreneur approach. Changes in cultural values on community-based tourism can be anticipated by their own
\end{abstract}

Keywords: E-tourism, Go digital, Cultural value, Community based tourism

\section{Introduction}

The existence of Community-based tourism (CBT) as a model of sustainable tourism development has been recognized by the world. CBT is very useful and effective for local people in income distribution, livelihood diversification, cultural preservation, environmental conservation and providing opportunities for community development through education (Đurkin \& Peri, 2017). The success of CBT in developing tourism in the region should take account of elements of natural and cultural resources, where natural resources are well preserved, local economies and modes of production depend on the use of sustainable resources, unique cultures as ends; (2) community organizations in which people share awareness, norms, ideologies, have a sense of belonging and participate in development and have leaders who understand local traditions and knowledge, local policies; and (3) management in which societies have rules and regulations for the environment, culture and management of tourism, local organizations or mechanisms for managing tourism, the benefits gained are distributed equitably to society and to public funds (Purbasari1 \& Asnawi, 2014). As well as CBT in Thailand, the research of Nick Kontogeorgopoulus, Anuwat 
Churyen and Varaphorn Duangseng (2014) in Mae Kampong, Thailand suggests that the success of CBT development is influenced by the recognition of the benefits of tourism, aiming, incorporating tourism-related stakeholders, and legitimate leadership involvement (Kontogeorgopoulos, Nick; Churyen, Anuwat; Duangsaeng, 2014). They recognize the success of CBT obtained with long-term and external relationships (Kontogeorgopoulos, Nick; Churyen, Anuwat; Duangsaeng, 2014).

CBT is related to external, including stakeholders, other communities, tourists and government. CBT is a small-scale government either Central Government or local governments .One of them is tourism development strategy launched by the Ministry of Tourism (2014) that is E-Tourism. E-Tourism is a digital platform that connects all tourism stakeholders, simplifies the licensing process, integrates all tourism activities and makes it easy for all travelers to explore the charm of Indonesia through its easy-to-use applications, whenever and wherever. Digitalization of this tourism aims to reach tourist arrivals of 20 million in 2019. Not all CBT using the digitalization of tourism to market and promote tourism products because of limited resources. But with e-tourism policy, CBT is required to implement it. Whereas, implementation of e-tourism is bringing change to CBT. These changes have an impact in CBT, especially the CBT culture. According to Eka Ardianto (2012), CBT dimension consists of two dimensions, namely CBT context and CBT Content. In the context of CBT, it consists of internal stakeholders (community and inter-community) and external (tourists and companies). While the content of CBT that is integration and relationships. Integration is defined as the existence of CBT described through CBT's operational business and implementation of beliefs. And relations are defined as CBT relationships with other communities. Contents dimensions and CBT context include entrepreneurial, inspirational, social and cultural elements (Ardianto, 2012b). In this article examines the e-tourism implications that occur in CBT, especially in the field of culture. The uniqueness and richness of the CBT culture integrated with this digitalization of tourism change will be discussed and this article assesses how e-tourism implications in CBT culture. The method used is the literature review of books, journals, web sites associated with articles over the past 10 years. The benefits of this study contribute as input to central government policy. 


\section{Result and discussion}

\section{The values of community-based tourism}

\begin{tabular}{|l|l|l|}
\hline $\begin{array}{c}\text { Implementation of } \\
\text { E-Tourism }\end{array}$ & \multicolumn{1}{|c|}{$\begin{array}{c}\text { The value of community } \\
\text { based tourism }\end{array}$} & \multicolumn{1}{|c|}{ Value Change } \\
\hline Marketing & social & Concern focus costumers \\
\hline Business & enterpreneural & Concern focus business economy \\
\hline Tourism & inspirations & Concern focus Environment \\
\hline & cultural & Concern focus society \\
\hline
\end{tabular}

Adaptation of Ardianto ( 2012), Hoarau-Heemstra \& Eide ( 2016) dan Jonathan \& Tarigan ( 2016)

Community-based tourism values infiltrated in Community-Based Tourism (CBT) activities invite tourists to discover wildlife and local habitats, celebrate and respect the traditional culture, rituals and wisdom it has. Communities recognize commercial and social value in the natural and cultural heritage through tourism, and community-based conservation. Okazaki (2008) developed the CBT model integrating the concept of ladder participation, power redistribution, collaborative processes, and social capital. Studies show that models can be used to assess the level of community participation (Okazaki, 2008). Changes in the community to maintain the attachment of members of the community or increase the opportunity of community members to escape.

Currently, tourism development affects people's support for business sustainability and their interaction with tourists. This support and interaction affects the overall success of tourism development. The development of ICT and the existence of e-tourism require CBT to adopt and make innovations. CBT creates local, family and own businesses with a substantial knowledge of usability, adoption, and socio-cultural issues (Armenta, Serrano, Cabrera, \& Conte, 2012). CBT accessing e-tourism requires digital access capability not only material access, product usage skills, content and others (Minghetti \& Buhalis, 2010). CBT can interact with tourists on line through e-tourism. Tourists can visit on line tours, communicate, transact and evaluate (Minghetti \& Buhalis, 2010). Online reviews and comments during interaction affect the purchasing decisions of tourists, which affect the evolution of demand in society. In this case, virtual communities play an important role in enhancing tourism product innovation by leveraging learning from customer relationships.

On the concern for customers, tourists can be a source of innovation because CBT gets economic benefits, innovation results that increase creativity and show high expertise to meet the needs of customers. Tourists are guarded and deemed very important in the continuity of CBT business and innovation progress (Hoarau-Heemstra \& Eide, 2016; Minghetti \& Buhalis, 2010).

Refer to environment aspect, tourists and stakeholders shows the concern and the importance of seeing environmentally responsible practices and innovations sustained by tourism businesses. The quality of tourist destinations is related to the decision of tourists to 
visit. Thus, CBT and the surrounding environment are motivated incentives to raise awareness and action and often innovate on charging marketing materials, increasing tourist visits and economic value (Hoarau-Heemstra \& Eide, 2016).

Cultural and heritage values are important to encourage creation, innovation and community development. In the concern for society, the values of appreciation and preservation of cultural heritage are important in innovating. The study found the importance of people learning about the history and culture of an area and collaborated into the concept of total tourist experience (Hoarau-Heemstra \& Eide, 2016).

In concern for business, innovation becomes a long-term investment that does not get immediate profits. With innovation, visit more tourists and earn more money (economies of scale) to grow business to other areas. The innovation and development of the products that follow have cycles and often blend balanced values and concerns. Each member of the CBT was cast on the quality of the experience and judgement of tourists so that a member of the CBT is an important part of the development of CBT. CBT maintains, trains and ensures team spirit is a requirement of the competence and quality of CBT organization itself. CBT conducts social activities and organizes regular meetings in which each member can discuss experiences, pressures, developments and share solutions. Another strategy for improving job satisfaction is to give people increased responsibility for each CBT member to gain innovative potential and creativity openly (Hoarau-Heemstra \& Eide, 2016).

The dynamics and use of new technologies in tourism development, CBT has undergone a change in adoption and behavior. CBT receives external values due to interaction through on-line. CBT's existing cultural values are revitalized (Ogaboh Agba, Ikoh, Bassey, \& Ushie, 2010). The change in the value of CBT does not change the approach of sustainable tourism development.

\section{Community- Based Tourism}

\section{Definition of Community-Based Tourism}

ASEAN defines CBT as a tourism activity, owned and operationalized by society or coordination at the community level that contribute to the welfare of the community through sustainable livelihood support and protecting the value of social and cultural traditions and natural and cultural resources (ASEAN, 2016). CBT is considered as a community empowerment and grassroots form in local economic development (Ardianto, 2012a; Duris \& Peric, 2017; Anuwat; i Duangsaeng, 2014; Nurhidayati, 2007; Okazaki, 2008; Purbasari1 \& Asnawi, 2014). Thus the various definitions of CBT that have been proposed basically include the level of community involvement, the benefits to society and the control of tourism development.

\section{The Value of Community-Based Tourism}

Based on the definition of Community-based tourism (CBT), CBT emphasizes community empowerment and provides benefits and challenges on four factors, namely economic, socio-culture, environment and image of people's residence (Aris Anuar \& Mohd Sood, 2017, ASEAN, 2016) . CBT involves not only partnerships between tourism businesses and communities to benefit both, but also supporting the efforts of the tourism community, which ultimately enhances the collective wellbeing. 
Principle CBT (1) involves and empowers communities to ensure transparent ownership and management, (2) building partnerships with relevant stakeholders, (3) obtaining recognition from authorities and related, (4) improving social welfare and maintaining human dignity, (5) the benefit of a fair and transparent with the sharing mechanism, (6) enhance local and regional economic relations, (7) respect local culture and traditions, (8) contribute to the conservation of natural resources, (9) improve the quality of the visitor experience by strengthening the meaning of interaction host and guest, and (8) oriented towards financial independence (ASEAN, 2016). These CBT principles are integrated in performance standards as criteria, sub criteria and indicators. CBT performance standards provide direction to the community on the quality of services provided to tourists to be consistent. With the principles of CBT it can be argued that the CBT dimension consists of CBT context and CBT content (Ardianto, 2012). The CBT context consists of internal stakeholders (community and between communities) and external stakeholders (tourists and companies) while CBT content consists of integration and relationships. Integration is defined as the existence of society in carrying out beliefs and business while relationships are defined as the existence of society in relation to other societies and tourists who are studying other communities and interacting with tourists (Ardianto, 2012c). In the CBT dimension there are inspirational,entrepreneurial cultural and social factors (Ardianto, 2012c). These factors have a unique combination and infiltrate the taste, innovation and operations of CBT. Hindertje Hoarau-Heemstra and Dorthe Elde (2016) distinguish four types of value innovation categories (1) for costumers with sub categories of well being, core product (experience), reliving the experience, (2) for environtment with sub category gray environment, green environment, including wildlife, (3) for society with culture and heritage and research and education category, (4) for business economy with profit and employees category (Hoarau-Heemstra \& Eide, 2016). The dynamics and linkages of CBT values are always formed through the interaction and collectivity of existing practices.

\section{E-tourism}

\section{Definition of E-tourism}

The concept of e-Tourism in question is the use of information and communication technology to increase the efficiency of tourism, provide various tourism services to customers, and make the implementation of tourism marketing more accessible in the form of Telematics (Condratov, 2013; Lumenta \& Sugiarso, 2015) . ETourism Development related to ICT development. ICT is a technology of procurement, processing, storage, and dissemination of various types of information by utilizing computers and telecommunications to overcome the slowness of human information processing (Armenta et al., 2012; Lumenta \& Sugiarso, 2015). ICT domains as the special headquarters of instruments with various series and services facilitate the interaction between market participants and world markets while the e-tourism domains identified the technological progress and the impact on the tourism market (Condratov, 2013). E-tourism with major internet distribution channels with marketing, business and tourism aspects influenced the use of ICT and how to influence the growth of the tourism 
industry (Lumenta \& Sugiarso, 2015). E-tourism includes social media, websites, mobile applications, blogs and others.

\section{Innovation in e-tourism}

E-tourism is a digital platform containing news data, events and destinations managed by the user (Lumenta \& Sugiarso, 2015). Similarly, with CBT, managing the etourism. CBT appoints members to manage the digital platform, always updating news, events and profiles of tourism destinations. CBT accesses e-tourism to add, edit and delete. CBT adopts e-tourism quickly. The relevance research previously conducted by Tai-Kuei Yu, Mei-Lan Lin, Ying-Kai Liao (2017) shows that ICT adoption behavior is related to task characteristics. Users are more likely to utilize ICT media features when they are better able to do so for communicative tasks. With complex tasks, communication is more frequent; In addition, the more diverse ICT content media, the greater the effect of content on ICT adoption behavior. Finally, further research should focus on two variables of "information literacy" and "digital skills." Future researchers can combine both direct and indirect measurement instruments in their new research designs (Yu, Lin, \& Liao, 2017).

\section{The relationship between e-tourism and community-based tourism}

Claresta Janice Jonathan and Riswan Efendi Tarigan (2016) argue that e-tourism contributes to the success of the tourism industry in other words as e-tourism increases the economic size of the tourism industry (Jonathan \& Tarigan, 2016). The dimensions and attributes of e-tourism include performance, market orientation, relationship, e-marketing, internet usability, applications, attitudes, perceptions, and disadvantages, potential, utilization, incentive, relationship quality, distribution sites, classification, inhibiting factors, success factors, staging, functions, and features (Jonathan \& Tarigan, 2016). These dimensions fall within the tourism system consisting of elements developed and managed by tourism destination managers. These elements include accessibility, attractions and amenity, called 3A and become a strategic program for the development of tourism destinations through the development of attractions, accessibility, and amenity (Kementerian Pariwisata, 2017). The development of attractions is done with the enhancement of natural tourist attraction, cultural tourism and artificial tourism conducted arrangements that attract tourists visiting. Amenity development is carried out with the development and maintenance of infrastructure, the provision of electricity and telecommunication services, the provision of sanitation and environmental sanitation, security facilities, tourism police, early warning system, 24 hour polyclinics, disability facilities, recreational facilities, accommodation, restaurants, tourism information center, souvenir shop, tourism sign and post in tourism destinations. Furthermore, increased accessibility is made by providing visit visa-free facilities, immigration checkpoints, immigration services, bilateral agreements, customs, quarantine, ports, construction or rehabilitation of infrastructure, transportation facilities and systems. Development of tourism destinations requires cross-sectoral support of government, private, and related stakeholders (Kementerian Pariwisata, 2017).

While e-tourism becomes the priority program of the Ministry of Tourism through digital marketing, digital sales process and internal management process digitally. Marketing 
consists of a digital website, internet advertising, and social media utilization. While the digital sales process consists of online ordering, integrated payments and management of digital products. The digital management process consists of digitally developing products, digital inventory management and Digital Back End reconciliation (Kementerian Pariwisata, 2017). The Ministry of Tourism embodies e-tourism by cooperating with Indonesia Tourism Exchange (ITX), a b2b (business to business) digital marketplace platform that brings together sellers (tourism service providers) with online travel agents (Kementerian Pariwisata, 2017). ITX makes it easy for tourist destinations to promote their regional potentials integrated into the platform, managers can self-manage, real time, affordable costs. The benefits of ITX are (1) access to more diverse, broader and real time products, low season opportunity opportunities, wider market access and free services (Kementerian Pariwisata, 2017)

E-tourism is socialized to all tourism business actors, not to mention CBT. CBT markets its services through e-tourism. CBT manages news data, events and tourist destinations and accesses e-tourism (Lumenta \& Sugiarso, 2015). The data consists of attractions, accessibility and amenity. CBT's local attractions with its uniqueness, CBT-like properties such as tourism facilities (homestays, restaurants, souvenir shops, tourism sign and posts), public facilities and adequate public facilities are informed in e-tourism. Additional information on visa-free visit facilities, access to tourist destinations, airports, ports, docks, terminals, trains and others are also informed in e-tourism. CBTs that have a tourism business can access ITX by registering first, filling out the cooperation agreement and signing the agreement. After registration is done booking system.

CBT markets tourism products and services that do not escape the local values of CBT. The uniqueness of the values of CBT is a tourist attraction. CBT makes innovations in conducting its business with sustainable tourism approaches and environmental conservation (Aris Anuar \& Mohd Sood, 2017, Hoarau-Heemstra \& Eide, 2016). Marketing and transactions on line going interaction between CBT with tourists, CBT with other communities or stakeholders related, the process of exchange of values appears. There has to be negotiation interaction on line for marketing and sale how local values are controlled in the interest of sustainability.. The online community grows and plays an important role in improving in life. People's behavior is played around the world both offline and online (aided or unaided by offline platforms), and astride some communities that are concurrent memberships. The Internet provides people with a large amount of potential benefits. The first type of benefits is access, through social networks, to online. Social capital is formed. The seeking, giving and sharing of knowledge, experiences and lessons across different individuals generate an ongoing coalescence of relationships and growth of networks that have a life of their own; one interaction feeds into another. This, over time, generates a dynamic buildup that forms an asset or capital (or more specifically, social capital) for the participants concerned(Wang, Walther, \& Hancock, 2009).

In particular, entrepreneurs can find in virtual communities incongruous idea combinations, and can also engage virtual community members with the refining of these ideas in a 'live' manner, for instance by thinking up new solutions aloud and engaging virtual community members in further developing the ideas. Such entrepreneurship can be characterized as a form of entrepreneurship of and for the community. by holding accessible 
knowledge developed in different circumstances, in different cultures, but available to all members, virtual communities enable the repurposing of ideas for new uses and a transformative influence on individual identity itself (Demangeot, 2015).

Resilience, which provides the ability to resist, adapt and flourish in the face of adversity, is the key to the survival and flourishing of communities. It is an attribute available to members of a community. Until now communities, especially those living in the margins with threats of economic, social and environmental crisis were considered to be purely at the mercy of governmental help or private philanthropy. Communities and their enterprising members around the world are showing an alternative, which is aided by the Internet. As argued earlier, virtual communities such as subject-specific online forums can enhance vulnerable communities' adaptation and resilience by providing people with access to both valuable knowledge and social support(Demangeot, 2015)

\section{Conclusion}

Internet users in Indonesia have reached $51 \%$, social media users $40 \%$, mobile subscribers $142 \%$ and mobile social users $35 \%$. Indications contained in the data, the central government policy of Go Digital in the tourism sector (E-Tourism) is considered appropriate for the development of Indonesian tourism, so as to capture the number of tourist visits to 20 million in 2019. E-tourism which consists of aspects namely marketing, business and tourism is encouraging CBT to innovate entrepreneurship, business, and develop the community. The success of CBT in developing tourism in the region should pay attention to the elements of tourism. Tourism development affects people's support for business sustainability and their interaction with tourists. CBT makes innovations in conducting its business with sustainable tourism approaches and environmental preservation. CBT's local values survive with revitalization, not altering the nature, form of adoption of social change.

\section{References}

Ahebwa, W. M., Aporu, J. P., \& Nyakaana, J. B. (2016). Bridging community livelihoods and cultural conservation through tourism: Case study of kabaka heritage trail in Uganda. Tourism and Hospitality Research, 16(2), 103-115. https://doi.org/10.1177/1467358415589659

Ardianto, E. (2012). Dimensions of community-based tourism: A case of surf community in Bali, Indonesia. Journal of Tourism Research, 5, 38-46.

Aris Anuar, A. N., \& Mohd Sood, N. A. A. (2017). Community based tourism: Understanding, benefits and challenges. Journal of Tourism \& Hospitality, 6(1), 1000263. https://doi.org/10.4172/2167-0269.1000263

Armenta, A., Serrano, A., Cabrera, M., \& Conte, R. (2012). The new digital divide: The confluence of broadband penetration, sustainable development, technology adoption and community participation. Information Technology for Development, 18(4), 345353. https://doi.org/10.1080/02681102.2011.625925

ASEAN. (2016). ASEAN COMMUNITY BASED. Jakarta: ASEAN Secretariat. Retrieved from www.asean.org 
Brilitiantoro, R. (2014). E-Tourism _ Strategi Baru Pariwisata Indonesia. Retrieved from http://pontinesia.com/index.php?berita\&id=14

Condratov, I. (2013). E-tourism : Concept and evolution. Ecoforum, 2(1), 58-61.

Crnojevac, I. H., Gugic, J., \& Karlovcan, S. (2010). eTourism : A comparison of Online and Offline Bookings and the Importance of Hotel Attributes. Journal of International Organizations Studies, 34(1), 41-54.

Davidson, R. M., Harris, R. W., \& Vogel, D. (2014). E-commerce for Community-Based Tourism in Developing Countries in Developing Countries. Retrieved December 29, 2017, from https://www.researchgate.net/publication/228843439

Demangeot, K. S. C. (2015). Conseptualizing virtual communities as enablers of communitybased enterpreneurship and resilience. Journal of Enterprising Communities: People and Places in the Global Economy, 11(1). https://doi.org/10.1108/17506200910999101

Durkin, J., \& Peric, M. (2017). Organising for community- based tourism: Comparing attitudes of local residents and local tourism entrepreneurs in Ravna. Local Economy, 32(7), 678-691. https://doi.org/10.1177/0269094217734811

Elmasry, T., Benni, E., Patel, J., \& aus dem Moore, J. P. (2016). Digital Middle East: Transforming the region into a leading digital economy. Retrieved from www.mckinsey.com

Giampiccoli, A., \& Kalis, J. H. (2012). Tourism, food, and culture: Community-based tourism, local food, and community development in Mpondoland. The Journal of Culture \& Agriculture, 34(2), 101-123. https://doi.org/10.1111/j.21539561.2012.01071.x

Himawan, H. (2015). E-tourism : Antara konsep dan implementasi dalam mendukung industri pariwisata Indonesia. Seminar Nasional Informatika (SEMNASIF), 1(5), 214-221. Retrieved from http://jurnal.upnyk.ac.id/index.php/semnasif/article/view/935

Hoarau-Heemstra, H., \& Eide, D. (2016). Values and concern: Drivers of innovation in experience-based tourism. Tourism and Hospitality Research, O(0), 1-12. https://doi.org/10.1177/1467358416683768

Jamal, S. A., Othman, N., \& Muhammad, N. M. N. (2011). Tourist perceived value in a community-based homestay visit: An investigation into the functional and experiential aspect of value. Journal of Vacation Marketing, 17(1), 5-15. https://doi.org/10.1177/1356766710391130

Jonathan, C. J., \& Tarigan, R. E. (2016). The Effects of e-tourism to the development of tourism sector in Indonesia. CommIT (Communication \& Information Technology) Journal, 10(2), 59-62.

Kementerian Pariwisata. (2017). Memahami Destinasi dan Industri Pariwisata. Jakarta: Deputi Bidang Pengembangan Destinasi dan Industri Pariwisata.

Kemp, S. (2017). 2017 Digital yearbook - internet, social media, and mobile data for 239 countries around the world. hootsuite we are social. Retrieved from http://www.mikekujawski.ca/wp-content/uploads/2017/02/We-Are-Social-DigitalYearkbook-2017.pdf

Kemp, S., Okazaki, E., Mkono, M., Tribe, J., Ahebwa, W. M., Aporu, J. P., ... Parnwell, M. J. G. (2017). Keberhasilan community based tourism di desa wisata Kembangarum, 
Pentingsari dan Nglanggeran. Journal of Travel Research, 34(1), 476-485. https://doi.org/10.1108/17506181011081523

King, V. T., \& Parnwell, M. J. G. (2011). World heritage sites and domestic tourism in Thailand. South East Asia Research, 19(3), 381-420. https://doi.org/10.5367/sear.2011.0055

Kontogeorgopoulos, Nick; Churyen, Anuwat; Duangsaeng, V. (2014). Success factors in community-based tourism in Thailand: The role of luck, external support, and local leadership. Tourism Planning \& Development, 11(1).

Lumenta, A. S. M., \& Sugiarso, B. A. (2015). E-tourism kabupaten pulau Morotai. E-Journal Teknik Elektro Dan Komputer, 71-78.

Minghetti, V., \& Buhalis, D. (2010). Digital divide in tourism. Journal of Travel Research, 49(3), 267-281. https://doi.org/10.1177/0047287509346843

Mkono, M., \& Tribe, J. (2017). Beyond reviewing: Uncovering the multiple roles of tourism social media users. Journal of Travel Research, 56(3), 287-298. https://doi.org/10.1177/0047287516636236

Nicely, A., \& Sydnor, S. (2015). Rural tourism development: tackling a culture of local nonparticipation in a postslavery society. Journal of Travel Research, 54(6), 717-729. https://doi.org/10.1177/0047287514535846

NN. (2015). E-Tourism solusi promosi bagi pariwisata Indonesia. Retrieved January 9, 2018, from http://marketeers.com/e-tourism-solusi-promosi-bagi-pariwisata-indonesia/

Noviyanti, S. (2014). E-Tourism", Bentuk promosi pariwisata Indonesia selanjutnya. $\begin{array}{llll}\text { Retrieved January } & 9, & \text { 2018, }\end{array}$ http://travel.kompas.com/read/2014/12/24/143100127/.ETourism.Bentuk.Promosi.Pariwisata.Indonesia.Selanjutnya

Nurhidayati, S. E. (2007). Community Based Tourism ( CBT ) sebagai pendekatan pembangunan pariwisata berkelanjutan. Www.journal.unair.ac.id.

Ogaboh Agba, A. M., Ikoh, M. U., Bassey, A. O., \& Ushie, E. M. (2010). Tourism industry impact on Efik's culture, Nigeria. International Journal of Culture, Tourism and Hospitality Research, 4(4), 355-365. https://doi.org/10.1108/17506181011081523

Okazaki, E. (2008). A community-based tourism model: its conception and use. Journal of Sustainable Tourism, 16(5), 511-529. https://doi.org/10.1080/09669580802159594

Pan, B. (2015). E-Tourism. https://doi.org/10.13140/2.1.3121.5681

Purbasari, N., \& Asnawi, D. (2014). Keberhasilan community based tourism di desa wisata Kembangarum, Pentingsari dan Nglanggeran. Teknik PWK, 3(3), 476-485. Retrieved from

http://download.portalgaruda.org/article.php?article=164661\&val=4689\&title=KEBE RHASILAN C

Schwab, P. K., Martin, C., Samans, R., Moavenzadeh, J., \& Drzeniek-Hanouz, M. (2017). The travel \& tourism competitiveness report 2017: paving the way for a more sustainable and inclusive future. https://doi.org/ISBN-13: 978-1-944835-08-8

Wamuyu, P. K. (2015). The Impact of information and communication technology adoption and diffusion on technology entrepreneurship in developing countries: The case of Kenya. Information Technology for Development, 21(2), 253-280. https://doi.org/10.1080/02681102.2014.948372 
World Economic Forum. (2017). The Global Competitiveness Report. (P. K. Schwab, Ed.). https://doi.org/92-95044-35-5

Yu, T.-K., Lin, M.-L., \& Liao, Y.-K. (2017). Understanding factors influencing information communication technology adoption behavior: The moderators of information literacy and digital skills. Computers in Human Behavior, 71, 196-208. https://doi.org/10.1016/j.chb.2017.02.005 